\title{
PENGGUNAAN TERAK NIKEL SEBAGAI AGREGAT DALAM CAMPURAN BETON
}

Wayan Mustika $^{1}$, I M. Alit K. Salain ${ }^{2}$,I K. Sudarsana ${ }^{2}$

\begin{abstract}
Abstrak : Terak nikel adalah salah satu jenis limbah peleburan bijih nikel setelah melalui proses pembakaran. Produksi dari terak nikel PT. Aneka Tambang Pomalaa Kabupaten Kolaka Propinsi Sulawesi Tenggara selama kurun waktu periode 2011-2012 sekitar 1 juta ton terak, dengan kandungan nikel dalam pengolahan biji nikel adalah antara 1,80\% sampai 2,00\%. Secara visual, bentuk fisik dari terak nikel ini menyerupai agregat. Penelitian ini dilaksanakan dengan menggunakan benda uji berbentuk silinder dengan diameter $15 \mathrm{~cm}$ dan tinggi $30 \mathrm{~cm}$ sebanyak 48 buah yang diuji pada umur 28 hari dengan beberapa variasi campuran. Variasi 01, 100\% agregat alami, variasi 02, terak nikel sebagai agregat kasar, variasi 03, terak nikel sebagai agregat halus, dan variasi 04, terak nikel sebagai agregat kasar dan agregat halus. Gradasi agregat dalam campuran ditetapkan dan dirancang sehingga memenuhi spesifikasi gradasi campuran untuk ukuran agregat maksimum $40 \mathrm{~mm}$. Komposisi campuran beton yang digunakan adalah campuran beton dengan perbandingan semen : aggegat halus : agregat kasar adalah $1: 2: 3$ dalam perbandingan berat dengan faktor air semen (fas) ditetapkan adalah sebesar 0,5. Hasil penelitian menunjukkan bahwa jika dibandingkan dengan penggunaan agregat alami, terak nikel yang digunakan hanya sebagai agregat kasar, sebagai agregat halus saja dan gabungan agregat kasar dan agregat halus mengakibatkan nilai slump berturut-turut turun 39,47\%, meningkat sebesar 55,26 \%, dan meningkat sebesar 34,21\%. Sebagai agregat kasar, terak nikel meningkatkan nilai kuat tekan, modulus elastisitas dan kuat tarik belah berturut-turut sebesar $42,27 \%, 19,37 \%$ dan 23,46\%. Sebagai agregat halus, terak nikel mengakibatkan nilai kuat tekan, modulus elastisitas dan kuat tarik belah turun berturut-turut sebesar $16,75 \%, 6,70 \%$ dan 24,58\%. Sebagai gabungan agregat kasar dan halus, terak nikel meningkatkan nilai kuat tekan, modulus elastisitas dan kuat tarik belah berturut-turut sebesar 10,31\%, 9,26\% dan 6,70\%.
\end{abstract}

Kata kunci : terak nikel, nilai slump, kuat tekan, modulus elastisitas, kuat tarik belah

\section{THE USE OF NICKEL SLAG AS AGGREGATE OF THE CONCRETE MIXTURE}

\begin{abstract}
Nickel slag is one kind of nickel ore smelting waste after the combustion process. Production of nickel slag PT. Antam Pomalaa Kolaka Southeast Sulawesi province during the period 2011-2012 period approximately 1 million tons of slag / year, with a nickel content in ore processing of nickel is between $1.80 \%$ to $2.00 \%$. Visually, the physical form of this nickel slag aggregate resembles. Research on the use of nickel slag as an aggregate in concrete mixture is carried out using a cylindrical specimen with a diameter of $15 \mathrm{~cm}$ and $30 \mathrm{~cm}$ high by 48 pieces were tested at 28 days with some variations in the mix. Variation 01, 100\% natural aggregate, variation 02 , nickel slag as coarse aggregate, variation 03 , nickel slag as fine aggregate, and variation 04, nickel slag as coarse aggregate and fine aggregate. Aggregate gradation in the mixture is set and is designed so that it meets the specifications gradation mix for maximum aggregate size of $40 \mathrm{~mm}$. The composition of the concrete mixture used is a mixture of concrete with the ratio of cement : fine aggegate : coarse aggregate is 1:2:3 in a weight ratio with cement water ratio (fas) is set at 0.5 . The results showed that when compared with the use of natural agregate, terak nickel is used only as a coarse agregate, a fine agregate only and combined agregate coarse and fine agregates resulting slump values fell $39.47 \%$, an increase of $55.26 \%$, and an increase of $34.21 \%$. As a coarse agregate, terak nickel increases the compressive strength, modulus of elasticity and splitting tensile strenght, respectively for $42.27 \%, 19.37 \%$ and $23.46 \%$. As fine agregate, nickel terak resulting value of compressive strength, modulus of elasticity and tensile strength divided down respectively by $16.75 \%$, $6.70 \%$ and $24.58 \%$. As a combination of coarse and fine agregate, terak nickel increases the compressive strength, modulus of elasticity and splitting tensile strenght, respectively for $10.31 \%, 9.26 \%$ and $6.70 \%$.
\end{abstract}

Keywords: nickel terak, value of slump, compressive strength, modulus of elasticity, splitting tensile strength

\footnotetext{
${ }^{1}$ Mahasiswa Program Magister Teknik Sipil, Program Pascasarjana, Universitas Udayana, Denpasar

${ }^{2}$ Staf Pengajar Program Magister Teknik Sipil, Program Pascasarjana, Universitas Udayana, Denpasar
} 


\section{PENDAHULUAN}

\section{Latar Belakang}

Terak nikel adalah salah satu jenis sisa dari proses industri yaitu akibat proses peleburan bijih nikel setelah melalui proses pembakaran dan penyaringan. Terak merupakan salah satu dari limbah hasil pengolahan nikel dari PT. Aneka Tambang Pomalaa yang terletak di Kabupaten Kolaka Propinsi Sulawesi Tenggara. Produksi dari terak selama kurun waktu periode 2011-2012 sekitar 1 juta ton terak/tahun, dengan kandungan nikel dalam umpan pengolahan biji nikel adalah antara 1,80\% sampai 2,00\% (http://www.antam.com).

Proses peleburan bijih nikel tersebut menghasilkan limbah berupa terak yang jumlahnya sangat besar. Terak tersebut harus ditangani atau dimanfaatkan dengan benar karena berpotensi menimbulkan masalah lingkungan serta fenomena sosial di masyarakat. Dengan demikian diharapkan dapat mengurangi efek pencemaran yang ditimbulkan dan juga dapat memberikan nilai ekonomis bagi terak tersebut.

Sebagai limbah buangan hasil pengolahan bijih nikel, selama ini terak hanya digunakan sebagai bahan timbunan yang kurang memiliki nilai ekonomis. Jika dilihat secara visual, bentuk fisik dari terak nikel ini menyerupai agregat baik yang halus menyerupai pasir maupun yang kasar menyerupai kerikil yang biasa digunakan untuk agregat dalam campuran beton.

\section{Tujuan Penelitian}

Tujuan penelitian ini adalah untuk:

1. Mengetahui nilai slump beton segar yang menggunakan terak nikel sebagai agregat pada campuran beton.

2. Mengetahui sifat mekanik beton yang dibuat dengan menggunakan terak nikel sebagai aggegat pada campuran beton

\section{KAJIAN PUSTAKA \\ Slag (Terak)}

Slag (terak) adalah limbah hasil industri dalam proses peleburan logam. Terak berupa residu atau limbah yang berwujud gumpalan menyerupai logam, memiliki kualitas rendah karena bercampur dengan bahan-bahan lain yang susah untuk dipisahkan. Terak terjadi akibat penggumpalan mineral silika, potas dan soda dalam proses peleburan logam atau melelehnya mineral-mineral tersebut dari bahan wadah pelebur akibat proses panas yang tinggi.

Slag (terak) adalah limbah buangan dari industri pengolahan nikel membentuk liquid panas yang kemudian mengalami pendinginan sehingga membentuk batuan alam yang terdiri dari terak padat dan terak yang berpori. Berdasarkan bentuknya, terak nikel dapat dibedakan menjadi 3 tipe yaitu high, medium, dan low slag. Terak nikel yang masuk kategori high diperoleh dari proses pemurnian di converter berbentuk pasir halus berwarna coklat tua, sedangkan kategori medium dan low slag diperoleh lewat tungku pembakaran (furnace).

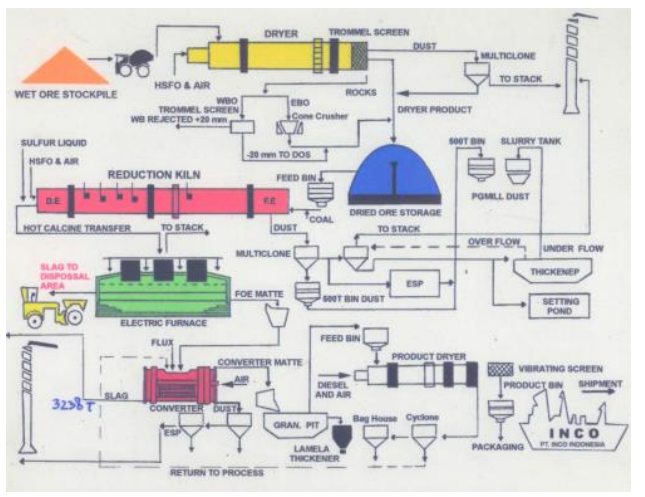

Gambar 1.

Proses Pembuatan Nikel (Sugiri, 2005)

Tabel 1.

Hasil Pengujian sifat fisik agregat terak nikel

\begin{tabular}{|l|r|r|r|}
\hline \multicolumn{1}{|c|}{ Pengujian } & $\begin{array}{c}\text { Terak } \\
\text { Nikel } \\
\text { Berpori }\end{array}$ & $\begin{array}{c}\text { Terak } \\
\text { Nikel } \\
\text { Padat }\end{array}$ & $\begin{array}{c}\text { Beton } \\
\text { normal- } \\
\text { Beton } \\
\text { Berat }\end{array}$ \\
\hline Berat Volume & 1327 & 1913 & 2.402 \\
\hline Specific gravity (SSD) & 2.835 & 3.215 & 3.858 \\
\hline Specific Gravity (Dry) & 2.692 & 3.179 & 3.848 \\
\hline Kadar Air (\%) & 0.11 & 0.11 & 0.1 \\
\hline Absorpsi(\%) & 5.301 & 1.151 & 0.1 \\
\hline
\end{tabular}

(Sugiri, 2005)

Tabel 2.

Komposisi kimia terak nikel

\begin{tabular}{|l|c|}
\hline \multicolumn{1}{|c|}{ Senyawa } & Jumlah (\%) \\
\hline Silika $\left(\mathrm{SiO}_{2}\right)$ & 41,47 \\
\hline Alumina $\left(\mathrm{Al}_{2} \mathrm{O}_{3}\right)$ & 2,58 \\
\hline Ferro oksida $\left(\mathrm{Fe}_{2} \mathrm{O}_{3}\right)$ & 30,44 \\
\hline Magnesia $(\mathrm{MgO})$ & 22,75 \\
\hline Alkalis $\left(\mathrm{Na}_{2} \mathrm{O}+\mathrm{K}_{2} \mathrm{O}\right)$ & 0,68 \\
\hline
\end{tabular}

(Sugiri, 2005)

\section{Sifat-Sifat Beton Segar}

Beton segar adalah beton dalam kondisi plastis (sebelum mengeras), dan akan segera mengeras dalam beberapa jam setelah beton diaduk. Beton segar harus mempunyai kinerja tinggi yaitu: workability atau kemudahan dikerjakan, kohesivitas dan kemudahan pemompaan ke tempat yang tinggi, panas hidrasi rendah, susut yang relative rendah pada proses pengerasan dan percepatan maupun 
penundaan waktu ikat awal. Sifat-sifat yang perlu diperhatikan pada beton segar adalah:

\section{Sifat Kemudahan dikerjakan (Workability)}

Sifat ini merupakan ukuran dari tingkat kemudahan adukan beton untuk diaduk, diangkut, dituang dan dipadatkan. Sifat kemudahan dikerjakan pada beton segar dipengaruhi oleh:

(1) Jumlah air yang dipakai dalam campuran adukan beton.

Semakin banyak air yang dipakai, semakin mudah beton segar dikerjakan tetapi jumlah air yang banyak dapat menurunkan kuat tekan beton.

(2) Penambahan semen ke dalam adukan. Makin banyak jumlah semen, maka beton segar makin mudah dikerjakan.

(3) Gradasi agregat halus dan kasar.

Apabila agregat yang digunakan mempunyai gradasi sesuai dengan persyaratan, maka adukan beton akan mudah dikerjakan.

(4) Bentuk butiran agregat.

Bentuk butiran agregat bulat akan lebih mempermudah pengerjaan beton.

(5) Penggunaan admixture dan bahan tambah mineral.

Tingkat kemudahan pengerjaan berkaitan erat dengan workability beton. Untuk mengukur workability beton dilakukan pengujian slump. Semakin besar nilai slump berarti adukan beton encer dan ini berarti beton semakin mudah dikerjakan.

Tabel 3.

Rekomendasi nilai slump untuk pemakaian beton segar pada elemen-elemen struktur

\begin{tabular}{|c|l|c|c|}
\hline No & \multicolumn{1}{|c|}{ Elemen Struktur } & $\begin{array}{c}\text { Slump } \\
\text { Maks } \\
(\mathrm{cm})\end{array}$ & $\begin{array}{c}\text { Slump } \\
\text { Min } \\
(\mathrm{cm})\end{array}$ \\
\hline 1 & $\begin{array}{l}\text { Plat pondasi, pondasi } \\
\text { telapak bertulang }\end{array}$ & 12,5 & 5,0 \\
\hline 2 & $\begin{array}{l}\text { Pondasi telapak tidak } \\
\text { bertulang, kaison dan } \\
\text { konstruksi di bawah } \\
\text { tanah }\end{array}$ & 9,0 & 2,5 \\
\hline 3 & $\begin{array}{l}\text { Plat (lantai), balok, } \\
\text { kolom dan dinding }\end{array}$ & 15,0 & 7,5 \\
\hline 4 & Jalan beton bertulang & 7,5 & 5,0 \\
\hline 5 & Pembetonan massal & 7,5 & 2,5 \\
\hline
\end{tabular}

$$
\text { (PBI } 1971 \text { N.I.-2) }
$$

\section{Sifat Mekanik Beton}

Sifat mekanik beton keras merupakan kemampuan beton di dalam memikul beban pada struktur bangunan. Kinerja beton keras yang baik ditunjukkan oleh kuat tekan beton yang tinggi, kuat tarik yang lebih baik, perilaku yang lebih daktail, kekedapan air dan udara, ketahanan terhadap sulfat dan klorida, penyusutan rendah dan keawetan jangka panjang.

\section{Kuat Tekan Beton}

Kuat tekan beton merupakan kekuatan tekan maksimum yang dapat dipikul beton per satuan luas. Kuat tekan beton normal antara 20-40 MPa. Kuat tekan beton dipengaruhi oleh: faktor air semen (water cement ratio $=$ w/c), sifat dan jenis agregat, jenis campuran, workability, perawatan (curing) beton dan umur beton. Faktor air semen (water cement ratio $=\mathrm{w} / \mathrm{c}$ ) sangat mempengaruhi kuat tekan beton. Semakin kecil nilai w/c nya maka jumlah airnya sedikit yang akan menghasilkan kuat tekan beton yang besar. Sifat dan jenis agregat yang digunakan juga berpengaruh terhadap kuat tekan beton. Semakin tinggi tingkat kekerasan agregat yang digunakan akan dihasilkan kuat tekan beton yang tinggi. Selain itu susunan besar butiran agregat yang baik dan tidak seragam dapat memungkinkan terjadinya interaksi antar butir sehingga rongga antar agregat dalam kondisi optimum yang menghasilkan beton padat dan kuat tekan yang tinggi.

Jenis campuran beton akan mempengaruhi kuat tekan beton. Jumlah pasta semen harus cukup untuk melumasi seluruh permukaan butiran agregat dan mengisi rongga-rongga diantara agregat sehingga dihasilkan beton dengan kuat tekan yang diinginkan. Untuk memperoleh beton dengan kekuatan seperti yang diinginkan, maka beton yang masih muda perlu dilakukan perawatan dengan tujuan agar proses hidrasi pada semen berjalan dengan sempurna. Pada proses hidrasi semen dibutuhkan kondisi dengan kelembaban tertentu. Apabila beton terlalu cepat mongering, akan timbul retak-retak pada permukaannya. Retak-retak ini akan menyebabkan kekuatan beton turun, juga akibat kegagalan mencapai reaksi hidrasi kimiawi penuh. Kuat tekan beton mengalami peningkatan seiring dengan bertambahnya umur beton. Kuat tekan beton dianggap mencapai $100 \%$ setelah beton berumur 28 hari.

Kuat tekan beton dihitung dengan rumus:

$$
\mathrm{f}^{\prime} \mathrm{c}=\frac{\mathrm{P}}{\mathrm{A}}
$$

dimana :

$\mathrm{f}^{\prime} \mathrm{c}=$ Kuat tekan beton $(\mathrm{MPa})$

$\mathrm{P}=$ beban maksimum $(\mathrm{N})$

$\mathrm{A}=$ luas bidang tekan benda uji $\left(\mathrm{mm}^{2}\right)$

$$
\mathrm{f}^{\prime} \mathrm{c}_{\text {rata-rata }}=\frac{\Sigma \mathrm{f}^{\prime} \mathrm{c}}{\mathrm{N}}
$$


dimana :

$$
\begin{aligned}
\mathrm{f}^{\prime} \mathrm{c}_{\text {rata-rata }}= & \begin{array}{l}
\text { Kuat tekan beton rata-rata } \\
(\mathrm{MPa})
\end{array} \\
\mathrm{N} & =\text { Jumlah benda uji (buah) }
\end{aligned}
$$

\section{Modulus Elastisitas}

Modulus elastisitas beton merupakan kemiringan garis singgung (slope dari garis lurus yang ditarik) dari kondisi tegangan nol ke kondisi tegangan 0,45 f'c pada kurva tegangan-regangan beton. Modulus elastisitas beton dipengaruhi oleh jenis agregat, kelembaban benda uji beton, faktor air semen, umur beton dan temperaturnya. Secara umum, peningkatan kuat tekan beton seiring dengan peningkatan modulus elastisitasnya.

Menurut pasal 10.5 SNI-03-2847 (2002) hubungan antara nilai modulus elastisitas beton normal dengan kuat tekan beton adalah Ec = $4700 \sqrt{f^{\prime} c}$

Modulus elastisitas beton dihitung dengan rumus :

$$
\begin{aligned}
& \mathrm{Ec}=\frac{\left(S_{2}-S_{1}\right)}{\varepsilon_{2}-0,000050} \\
& \mathrm{Ec}_{\text {rata-rata }}=\frac{\Sigma \mathrm{Ec}}{\mathrm{N}} \ldots \ldots
\end{aligned}
$$

Dimana :

$$
\mathrm{Ec}=\text { Modulus elastisitas beton }
$$
(MPa)

$S_{2}=$ Tegangan yang terjadi saat beban 40 $\% \mathrm{P}$ maksimum, $\mathrm{S}_{2}=\frac{P_{2}}{A}(\mathrm{MPa})$

$\mathrm{A}=$ Luas penampang silinder $\left(\mathrm{mm}^{2}\right)$

$\mathrm{P}_{2}=$ Beban pada saat $40 \% \mathrm{P}_{\text {mak }}(\mathrm{N})$

$\mathrm{S}_{1}=$ Tegangan yang terjadi saat regangan longitudinal mencapai 0,000050

(Mpa), $\mathrm{S}_{1}=\frac{P_{1}}{A}(\mathrm{MPa})$

$\mathrm{P}_{1}=$ Beban pada saat regangan mencapai 0,00005 . (N)

$\varepsilon_{2}=$ Regangan longitudinal pada saat beban mencapai $40 \%$ Pmak $\left(\mathrm{P}_{2}\right)$.

\section{Kuat Tarik Beton}

Salah satu kelemahan beton adalah mempunyai kuat tarik yang sangat kecil dibandingkan dengan kuat tekannya yaitu $10 \%-15 \%$ f'c. Kuat tarik beton berpengaruh terhadap kemampuan beton di dalam mengatasi retak awal sebelum dibebani. Pengujian terhadap Kekuatan tarik beton dapat dilakukan dengan cara: (1) Pengujian tarik langsung, (2) Pengujian tarik belah (pengujian tarik beton tak langsung). Dengan membelah silinder beton terjadi pengalihan tegangan tarik melalui bidang tempat kedudukan salah satu silinder dan silinder beton tersebut terbelah sepanjang diameter yang dibebaninya.
Kuat Tarik belah dari benda uji dihitung dengan rumus :

$$
\begin{aligned}
& \mathrm{F}_{\mathrm{ct}}=\frac{2 P}{\pi L D} \\
& \text { Dimana : } \\
& \mathrm{F} \quad \text { : kuat tarik belah (MPa) } \\
& \mathrm{P}^{\mathrm{ct}} \text { : beban uji maksimum (beban } \\
& \text { L : panjang benda uji selinder (mm) } \\
& \text { D : diameter benda uji silinder ( } \mathrm{mm})
\end{aligned}
$$

\section{METODE PENELITIAN}

\section{Rancangan Penelitian}

Penelitian ini dimulai dengan penyiapan sampel yang digunakan berupa agregat kasar, agregat halus, semen dan air serta sampel terak sebagai agregat kasar dan halus, selanjutnya dilakukan pengujian sifat karakteristik agregat yang digunakan berdasarkan metode SNI yang relevan meliputi pengujian kadar air, kadar lumpur, berat volume, berat jenis dan penyerapan air, dan pengujian keausan atau abrasi aggegat kasar. Pembuatan campuran beton terdiri dari:

1. Variasi 01 (V.01), campuran beton dengan $100 \%$ agregat normal (pasir dan kerikil) tanpa penambahan terak nikel,

2. Variasi 02 (V.02), campuran beton dengan terak nikel sebagai agregat kasar dan pasir sebagai agregat halus,

3. Variasi 03 (V.03), campuran beton dengan terak nikel sebagai agregat halus dan kerikil sebagai agregat kasar, dan

4. Variasi 04 (V.04), campuran beton dengan terak nikel sebagai agregat kasar dan agregat halus.

Penelitian ini bertujuan untuk mengetahui nilai slump dan sifat mekanik beton yang menggunakan material terak nikel dengan membandingkan dengan penggunaan material alami berupa kerikil dan pasir, dalam hal ini yang mengalami perubahan adalah jenis material agregat yang akan digunakan. Gradasi agregat dalam campuran ditetapkan dan dirancang dalam perbandingan berat sehingga memenuhi spesifikasi gradasi campuran untuk ukuran agregat maksimum $40 \mathrm{~mm}$ (tabel 2.3). Komposisi campuran beton yang direncanakan ditetapkan dengan perbandingan semen : aggegat halus : agregat kasar adalah $1: 2: 3$ dalam perbandingan berat dan faktor air semen (fas) sebesar 0,5.

Benda uji yang dibuat berupa silinder beton dengan ukuran diameter $150 \mathrm{~mm}$ dan tinggi $300 \mathrm{~mm}$ sebanyak 12 (dua belas) buah benda uji untuk tiap variasi campuran dengan rincian 
6 (enam) benda uji untuk pengujian kuat tekan dan modulus elastisitas beton, dan 6 (enam) benda uji untuk pengujian kuat tarik belah beton. Total benda uji silinder beton yang digunakan dalam penelitian ini adalah sebanyak 48 (empat puluh delapan) buah benda uji.

\section{Lokasi dan Waktu Penelitian}

Penelitian ini dilaksanakan di Laboratorium Pengujian Bahan dan Konstruksi pada Universitas Haluoleo Kendari dan di Laboratorium Struktur dan Bahan Fakultas Teknik Universitas Udayana Bukit Jimbaran Bali selama kurang lebih 45 hari.

\section{Variabel Penelitian}

Variabel penelitian ini terdiri dari variabel bebas dan terikat. Sebagai variabel terikat adalah perilaku beton segar dan beton keras yang terdiri dari : nilai slump, kuat tekan, modulus elastisitas, dan kuat tarik belah beton. Variabel bebas dalam penelitian ini adalah variasi jumlah terak nikel yang digunakan sebagai agregat.

Variasi penggunaan terak nikel sebagai pengganti agregat kasar pada campuran beton yang diteliti seperti pada Tabel 4 sebagai berikut:

\section{Tabel 4.}

Variasi Benda Uji

\begin{tabular}{|c|c|c|}
\hline $\begin{array}{c}\text { Kode } \\
\text { Benda } \\
\text { Uji }\end{array}$ & $\begin{array}{c}\text { Persentase Terak } \\
\text { Nikel Dalam } \\
\text { Campuran Beton } \\
(\%)\end{array}$ & Keterangan \\
\hline V.01 & 0 & tanpa terak \\
\hline V.02 & $50(3 / 6)$ & terak sebagai agregat kasar \\
\hline V.03 & $33,33(2 / 6)$ & terak sebagai agregat halus \\
\hline V.04 & $83,33(5 / 6)$ & $\begin{array}{c}\text { terak sebagai agregat kasar } \\
\text { dan halus }\end{array}$ \\
\hline
\end{tabular}

Sedangkan jenis pengujian dan jumlah benda uji yang dibuat untuk masing-masing variasi ditunjukkan pada tabel 5 berikut ini :

Tabel 5.

Jenis Pengujian dan Jumlah Benda Uji

\begin{tabular}{|c|c|c|}
\hline Jenis Pengujian & $\begin{array}{c}\text { Jumlah } \\
\text { Benda Uji } \\
\text { (buah) }\end{array}$ & $\begin{array}{c}\text { Umur } \\
\text { Pengujian } \\
\text { (hari) }\end{array}$ \\
\hline $\begin{array}{c}\text { Kuat tekan dan } \\
\text { modulus elastisitas }\end{array}$ & 24 & 28 \\
\hline Kuat tarik belah & 24 & 28 \\
\hline
\end{tabular}

\section{Bahan Penelitian}

Bahan yang digunakan dalam penelitian ini adalah berupa agregat halus, agregat kasar, semen, air dan terak nikel. Berikut adalah datadata material yang akan digunakan dalam penelitian ini :
Tabel 6.

Jenis dan Sumber material yang digunakan dalam penelitian

\begin{tabular}{|l|l|}
\hline Jenis Material & \multicolumn{1}{|c|}{\begin{tabular}{c}
\multicolumn{1}{c|}{ Tempat pengambilan material } \\
(asal)
\end{tabular}} \\
\hline $\begin{array}{l}\text { Agregat Kasar } \\
\text { (kerikil) }\end{array}$ & $\begin{array}{l}\text { Desa Longori Kecamatan Pomalaa } \\
\text { Kabupaten Kolaka, Sulawesi } \\
\text { Tenggara. }\end{array}$ \\
\hline $\begin{array}{l}\text { Agregat Halus } \\
\text { (pasir) }\end{array}$ & $\begin{array}{l}\text { Desa Longori Kecamatan Pomalaa } \\
\text { Kabupaten Kolaka, Sulawesi } \\
\text { Tenggara. }\end{array}$ \\
\hline $\begin{array}{l}\text { Semen Type I } \\
\text { (Tonasa) }\end{array}$ & Makassar (Sulawesi Selatan) \\
\hline $\begin{array}{l}\text { Terak Nikel } \\
\text { kategori low } \\
\text { slag }\end{array}$ & $\begin{array}{l}\text { Tempat Pembuangan Limbah Terak } \\
\text { Nikel PT. Antam Pomalaa } \\
\text { Kecamatan Pomalaa Kabupaten } \\
\text { Kolaka, Sulawesi Tenggara. }\end{array}$ \\
\hline
\end{tabular}

Air yang digunakan dalam penelitian ini adalah jenis air dari Perusahaan Daerah Air Minum (PDAM) yang dianggap telah memenuhi syarat untuk digunakan dalam campuran beton sehingga tidak dilakukan pemeriksaan terhadap kualitas air yang akan digunakan.

Dalam penelitian ini dilakukan perancangan gradasi agregat sehingga memenuhi spesifikasi gradasi campuran untuk ukuran agregat maksimum $40 \mathrm{~mm}$.

Rancangan kebutuhan material untuk pembuatan benda uji silinder beton selengkapnya pada lampiran.

Tabel 7.

Gradasi Campuran Yang Digunakan Dalam Penelitian

\begin{tabular}{|c|c|c|c|c|c|c|}
\hline \multicolumn{2}{|c|}{ Lubang Ayakan } & \multirow{2}{*}{$\begin{array}{l}\text { Kur- } \\
\text { va } 1\end{array}$} & \multirow{2}{*}{$\begin{array}{l}\text { Kur- } \\
\text { va } 2\end{array}$} & \multirow{2}{*}{$\begin{array}{l}\text { Kur- } \\
\text { va } 3\end{array}$} & \multirow{2}{*}{$\begin{array}{l}\text { Kur- } \\
\text { va } 4\end{array}$} & \multirow{2}{*}{$\begin{array}{c}\text { Gradasi } \\
\text { Campuran }\end{array}$} \\
\hline$(\mathrm{mm})$ & ASTM & & & & & \\
\hline 38 & $11 / 2$ & 100 & 100 & 100 & 100 & 100 \\
\hline 19 & $3 / 4$ & 50 & 59 & 67 & 75 & 65 \\
\hline 9,6 & $3 / 8 "$ & 36 & 44 & 52 & 60 & 50 \\
\hline 4,8 & No.4 & 24 & 32 & 40 & 47 & 40 \\
\hline 2,4 & No. 8 & 18 & 25 & 31 & 38 & 30 \\
\hline 1,2 & No. 16 & 12 & 17 & 24 & 30 & 21 \\
\hline 0,6 & No.30 & 7 & 12 & 17 & 23 & 15 \\
\hline 0,3 & No.50 & 3 & 7 & 11 & 15 & 9 \\
\hline 0,15 & No. 100 & 0 & 0 & 2 & 5 & 2,5 \\
\hline
\end{tabular}

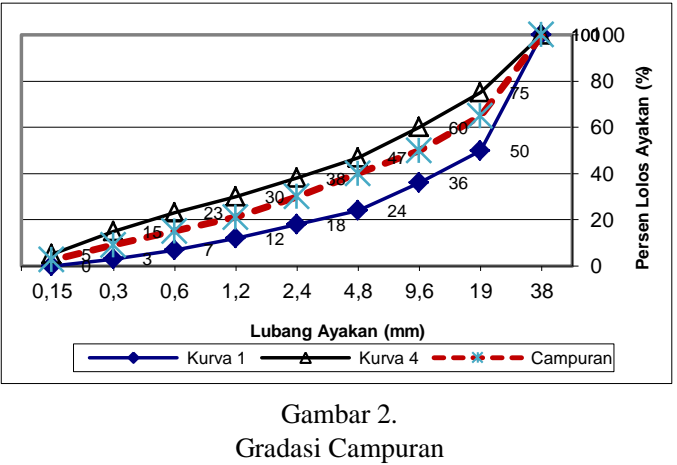

Prosedur Penelitian

Metode Pengujian Bahan

Sebelum dilakukan pembuatan benda uji beton, dilakukan pengujian terhadap 
karakteristik agregat kasar dan halus serta terak nikel. Untuk sifat-sifat Portland Cement (PC) tidak dilakukan pengujian karena menggunakan semen yang telah umum digunakan dan dianggap telah memenuhi persayaratan untuk semen portland type I. Adapun jenis dan standar pengujian yang digunakan meliputi :

1. Pengujian agregat kasar (terak dan kerikil) meliputi :

a. Pengujian kadar air agregat (SNI 031971-1990)

b. Pengujian kadar lumpur agregat (SNI 03-4142-1996)

c. Pengujian berat isi agregat (SNI 034804-1998)

d. Pengujian berat jenis dan penyerapan air agregat kasar (SNI 03-1969-2008)

e. Pengujian keausan agregat kasar dengan mesin los angeles (SNI 032417-2008)

2. Pengujian agregat halus (terak dan kerikil) meliputi :

a. Pengujian kadar air agregat (SNI 031971-1990)

b. Pengujian kadar lumpur agregat (SNI 03-4142-1996)

c. Pengujian berat isi agregat (SNI 034804-1998)

d. Pengujian berat jenis dan penyerapan air agregat halus (SNI 03-1970-2008)

\section{Pengujian Slump (Slump Test)}

Slump pada dasarnya merupakan salah satu pengetesan sederhana untuk mengetahui workability beton segar sebelum diterima dan diaplikasikan dalam pekerjaan pengecoran.

Workability beton segar pada umumnya diasosiasikan dengan :
a. Homogenitas
atau kerataan campuran adukan beton segar (homogenity)

b. Kelekatan adukan pasta semen (cohesiveness)

c. Kemampuan alir beton segar (flowability)

d. Kemampuan beton segar mempertahankan kerataan dan kelekatan jika dipindah dengan alat angkut (mobility)

e. Mengindikasikan apakah beton segar masih dalam kondisi plastis (plasticity).

Slump beton segar dilakukan sebelum beton dituangkan kedalam cetakan silinder benda uji. Pengukuran slump dilakukan dengan mengacu pada SNI 1972-2008 (Cara Uji Slump Beton).

\section{Pengujian Kuat Tekan Beton}

Kuat tekan beton diuji berdasarkan SNI 031974-1990. Pengujian kuat tekan dilakukan dengan pembebanan uniaksial dengan kecepatan pembebanan $2-4 \mathrm{~kg} / \mathrm{cm}^{2}$ per detik pada umur 28 hari. Dilaksanakan dengan menggunakan benda uji berbentuk silinder beton berdiameter $150 \mathrm{~mm}$ dan tinggi $300 \mathrm{~mm}$. Pengujian Modulus Elastisitas

Modulus elastisitas merupakan perbandingan dari tegangan yang diberikan dengan deformasi yang terjadi persatuan panjang akibat dari tegangan yang diberikan tersebut (Murdock and Brook, 1999). Pengujian tegangan dan regangan beton seperti pada gambar 3.3.

Pengujian dilakukan dengan menggunakan alat dial gauge untuk mengukur modulus elastisitas beton.

Benda uji silinder dilengkapi dengan alat pengukur perpendekan beton, dilakukan uji tekan beton dengan beban ditingkatkan secara perlahan kurang lebih sebesar $10 \mathrm{kN} /$ det.

\section{Pengujian Kuat Tarik Belah}

Pengujian kuat tarik belah beton dilaksanakan berdasarkan metode SNI 032491-2002. Benda uji berupa silinder ukuran diameter $15 \mathrm{~cm}$ dan tinggi $30 \mathrm{~cm}$, nilai kuat tarik tidak langsung dari benda uji beton berbentuk silinder yang diperoleh dari hasil pembebanan benda uji tersebut yang diletakkan mendatar sejajar dengan permukaan meja penekan mesin uji ditekan.

\section{HASIL DAN PEMBAHASAN \\ Hasil Pengujian \\ Slump Test}

Pengujian nilai slump dimaksudkan untuk mengetahui tingkat kekentalan dari adukan beton yang selanjutnya dapat menggambarkan workabilitas dari campuran beton. Adapun hasil pengujian slump selengkapnya pada Tabel 4.5 berikut ini.

Tabel 8.

Nilai Slump Campuran Beton

\begin{tabular}{|c|c|c|c|}
\hline \multirow{2}{*}{ No } & \multirow{2}{*}{$\begin{array}{c}\text { Jenis } \\
\text { Benda Uji }\end{array}$} & \multicolumn{2}{|c|}{ Nilai Slump Rata-Rata } \\
\cline { 3 - 4 } & $\mathbf{( m m )}$ & $\begin{array}{c}(\%) \text { Terhadap } \\
\text { V.01 }\end{array}$ \\
\hline 1 & V.01 & 95 & 100,00 \\
\hline 2 & V.02 & 57,5 & 60,53 \\
\hline 3 & V.03 & 147,5 & 155,26 \\
\hline 4 & V.04 & 127,5 & 134,21 \\
\hline
\end{tabular}

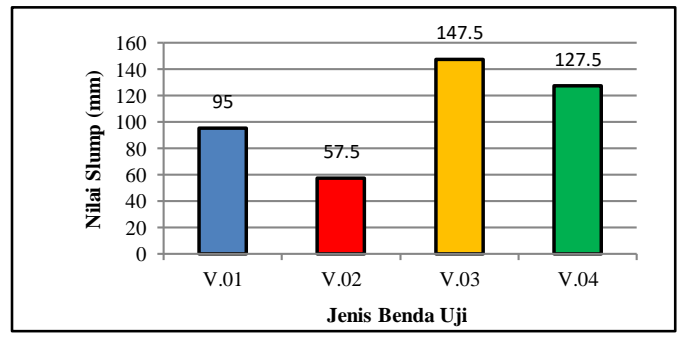

Gambar 3.

Nilai slump pada berbagai jenis variasi benda uji 
Pada Gambar 3, terlihat bahwa secara umum penggunaan terak nikel sebagai agregat dalam campuran beton berpengaruh terhadap tingkat kelecakan beton, terlihat bahwa penggunaan terak nikel sebagai agregat kasar (V.02) mengakibatkan terjadinya penurunan nilai slump campuran beton, sebaliknya penggunaan terak nikel sebagai agregat halus (V.03) dapat meningkatkan nilai slump campuran beton. Selanjutnya dengan penggunaan secara bersamaan terak nikel sebagai agregat kasar dan halus (V.04) menyebabkan terjadinya peningkatan nilai slump dibandingkan dengan penggunaan agregat kasar dan halus yang berasal dari agregat alami (V.01) maupun pada penggunaan terak nikel sebagai agregat kasar (V.02), namun nilainya masih lebih rendah jika dibandingkan dengan penggunaan terak nikel hanya sebagai agregat halus (V.03). Hal ini menunjukkan bahwa penggunaan terak nikel sebagai agregat kasar mengakibatkan terjadinya penurunan nilai slump, sedangkan penggunaan terak nikel sebagai agregat halus menyebabkan nilai slump campuran beton mengalami peningkatan. Penggunaan agregat kasar dan halus terak nikel secara bersamaan bersifat saling mengimbangi, sehingga tingginya nilai slump akibat penggunaan terak nikel sebagai agregat halus dapat diturunkan dengan penggunaan terak nikel sebagai agregat kasarnya.

\section{Berat Volume Beton}

Berat volume adalah perbandingan antara berat dan volume benda uji silinder yang digunakan dalam penelitian. Berat volume rata-rata benda uji dapat dilihat pada Tabel 9. di bawah ini :

Tabel 9.

Berat Volume Rata-Rata Benda Uji

\begin{tabular}{|c|c|c|c|}
\hline \multirow{2}{*}{ No } & \multirow{2}{*}{$\begin{array}{c}\text { Jenis } \\
\text { Benda Uji }\end{array}$} & \multicolumn{2}{|c|}{ Berat Volume Rata-Rata } \\
\cline { 3 - 4 } & $\mathbf{( K g / m 3 )}$ & $\begin{array}{c}\text { \% Terhadap } \\
\text { V.01 }\end{array}$ \\
\hline 1 & V.01 & 2510,03 & 100,00 \\
\hline 2 & V.02 & 2604,39 & 103,76 \\
\hline 3 & V.03 & 2598,10 & 103,51 \\
\hline 4 & V.04 & 2701,90 & 107,64 \\
\hline
\end{tabular}

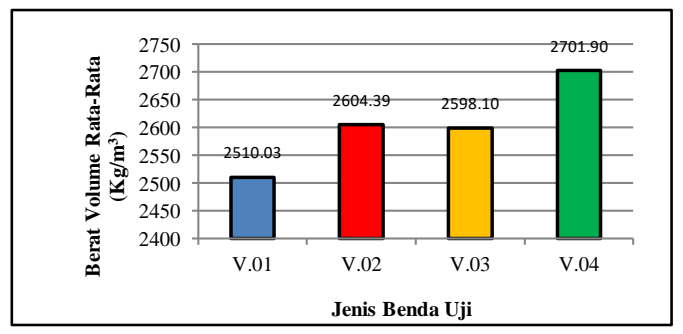

Gambar 4.

Berat volume pada berbagai jenis variasi benda uji
Berdasarkan data pada Tabel 9 dan Gambar 4 di atas terlihat bahwa berat volume beton rata-rata dengan menggunakan agregat alami (V.01) adalah sebesar 2510,03 Kg./ $/ \mathrm{m}^{3}$. Pada penggunaan terak nikel sebagai agregat kasar (V.02), sebagai agregat halus (V.03) dan secara bersamaan sebagai agregat kasar dan agregat halus (V.04) terjadi peningkatan berat volume beton berturut-turut sebesar 3,76\%, $3,51 \%$ dan $7,64 \%$ jika dibandingkan dengan berat volume beton yang menggunakan agregat alami (V.01).

Peningkatan berat volume beton pada penggunaan terak nikel sebagai agregat disebabkan oleh karena berat volume agregat terak nikel baik sebagai agregat kasar maupun sebagai agregat halus lebih besar jika dibandingkan dengan berat volume agregat alami.

\section{Kuat Tekan Beton}

Pengujian dilakukan pada umur 28 hari, perhitungan data hasil uji kuat tekan dilakukan menggunakan persamaan 1 dan 2. Data hasil pengujian kuat tekan beton dengan menggunakan terak nikel sebagai agregat baik sebagai agregat halus maupun sebagai agregat kasar dapat dilihat pada Tabel 10.

Tabel 10.

Nilai Kuat Tekan Campuran Beton

\begin{tabular}{|c|c|c|c|}
\hline \multirow{2}{*}{ No } & \multirow{2}{*}{$\begin{array}{c}\text { JenisBenda } \\
\text { Uji }\end{array}$} & \multicolumn{2}{|c|}{ Nilai Kuat Tekan Rata-Rata } \\
\cline { 3 - 4 } & V.01 & 18,31 & \% \\
\hline 1 & Merhadap V.01 \\
\hline 2 & V.02 & 26,04 & 100,00 \\
\hline 3 & V.03 & 15,24 & 142,27 \\
\hline 4 & V.04 & 20,19 & 83,25 \\
\hline
\end{tabular}

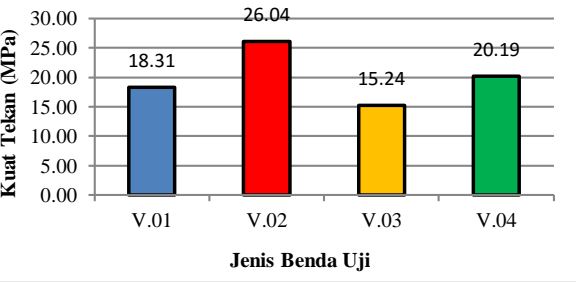

Gambar 5

Kuat tekan beton pada berbagai jenis variasi benda uji

Berdasarkan data pada Tabel 10 dan Gambar 5 di atas terlihat bahwa kuat tekan beton dengan menggunakan agregat alami (V.01) adalah sebesar 18,31 MPa. Pada penggunaan terak nikel sebagai agregat kasar (V.02) terjadi peningkatan sebesar 42,27\% dan juga meningkat sebesar $10,31 \%$ pada penggunaan terak nikel secara bersamaan sebagai agregat kasar dan agregat halus (V.04), pada penggunaan terak nikel hanya sebagai agregat halus (V.03) nilai kuat tekan turun sebesar 16,75 \% jika dibandingkan dengan 
nilai kuat tekan beton yang menggunakan agregat alami (V.01).

\section{Modulus Elastisitas Beton}

Pengujian tegangan regangan aksial beton menggunakan CTM (Compression Testing Machine) dan alat ukur regangan (ekstensometer). Pengambilan tegangan dan regangan aksial data dilakukan setiap penambahan beban dengan laju yang konstan yaitu setiap penambahan beban sebesar $20 \mathrm{kN}$.

Perhitungan modulus elastisitas beton menggunakan persamaan 3 dan 4. Modulus elastisitas beton yang diperoleh dari hasil pengujian dengan variasi penggunaan terak nikel sebagai agregat kasar dan agregat halus seperti pada Tabel 11 berikut:

Tabel 11.

Nilai Modulus Elastisitas Beton Rata-Rata

\begin{tabular}{|c|c|c|c|}
\hline \multirow{2}{*}{ No } & \multirow{2}{*}{$\begin{array}{c}\text { Jenis } \\
\text { Benda Uji }\end{array}$} & Modulus Elastisitas Rata-Rata \\
\cline { 3 - 4 } & (MPa) & $\begin{array}{c}\text { \% (terhadap } \\
\text { V.01) }\end{array}$ \\
\hline 1 & V.01 & 16006,71 & 100,00 \\
\hline 2 & V.02 & 19107,40 & 119,37 \\
\hline 3 & V.03 & 14934,45 & 93,30 \\
\hline 4 & V.04 & 17489,27 & 109,26 \\
\hline
\end{tabular}

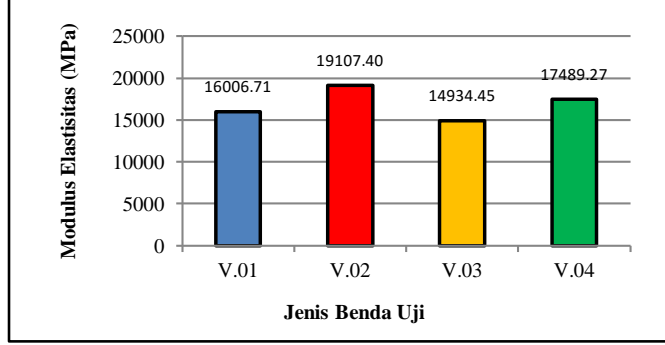

Gambar 6.

Modulus elastisitas beton pada berbagai jenis variasi benda uji

Gambar 6 menunjukkan bahwa modulus elastisitas beton dengan menggunakan agregat alami (V.01) adalah sebesar 16006,71 MPa. Pada penggunaan terak nikel sebagai agregat kasar (V.02) terjadi peningkatan sebesar $19,37 \%$ dan juga meningkat sebesar 9,26\% pada penggunaan terak nikel secara bersamaan sebagai agregat kasar dan agregat halus (V.04), pada penggunaan terak nikel hanya sebagai agregat halus (V.03) nilai modulus elastisitasnya turun sebesar $6,70 \%$ jika dibandingkan dengan nilai modulus elastisitas beton yang menggunakan agregat alami (V.01). Peningkatan dan penurunan nilai modulus elastisitas beton dengan menggunakan terak nikel sebagai agregat ini seiring dengan peningkatan dan penurunan nilai kuat tekan betonnya.

\section{Kuat Tarik Belah Beton}

Kuat tarik beton berpengaruh terhadap kemampuan beton di dalam mengatasi retak awal sebelum dibebani, secara umum besarnya kuat tarik beton adalah sebesar 10\% - 15\% dari nilai kuat tekannya (f'c). Perhitungan kuat tarik belah beton menggunakan persamaan 5 .

Hasil pengujian kuat tarik belah rata-rata dengan variasi penggunaan terak nikel sebagai agregat kasar dan agregat halus seperti pada Tabel 12 berikut:

Tabel 12.

Hasil Uji Kuat Tarik Belah Beton

\begin{tabular}{|c|c|c|c|}
\hline \multirow{2}{*}{ No } & \multirow{2}{*}{$\begin{array}{c}\text { Jenis } \\
\text { Benda }\end{array}$} & \multicolumn{2}{|c|}{ Kuat Tarik Belah Rata-Rata } \\
\cline { 3 - 4 } & Uji & $(\mathbf{M P a})$ & \% (Terhadap V.01) \\
\hline 1 & $\mathrm{~V} .01$ & 2,11 & 100,00 \\
\hline 2 & $\mathrm{~V} .02$ & 2,61 & 123,46 \\
\hline 3 & $\mathrm{~V} .03$ & 1,59 & 75,42 \\
\hline 4 & $\mathrm{~V} .04$ & 2,25 & 106,70 \\
\hline
\end{tabular}

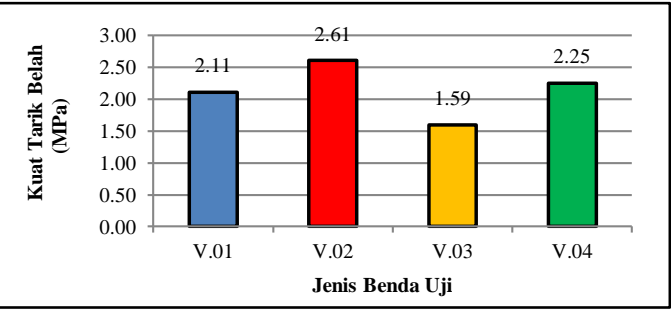

Gambar 7.

Kuat tarik belah beton pada berbagai jenis variasi benda uji

Berdasarkan data pada Tabel 12 dan Gambar 7 di atas terlihat bahwa kuat tarik belah beton dengan menggunakan agregat alami (V.01) adalah sebesar 2,11 MPa. Pada penggunaan terak nikel sebagai agregat kasar (V.02) terjadi peningkatan nilai kuat tarik belah sebesar $23,46 \%$ dan juga meningkat sebesar $6,70 \%$ pada penggunaan terak nikel secara bersamaan sebagai agregat kasar dan agregat halus (V.04), pada penggunaan terak nikel hanya sebagai agregat halus (V.03) nilai kuat tarik belahnya turun sebesar 24,58 \% jika dibandingkan dengan nilai kuat tarik belah beton yang menggunakan agregat alami (V.01).

Pembahasan

Pengaruh Penggunaan Terak Nikel Sebagai Agregat dalam Campuran Beton Terhadap Nilai Slump

Salah satu faktor yang mempengaruhi nilai slump beton adalah bentuk butiran agregat kasarnya (Mulyono, 2003). Selain itu dalam penelitian ini akibat penggunaan terak nikel sebagai agregat kasar menyebabkan berkurangnya volume agregat kasar karena berat volume yang berbeda, sehingga untuk kasus V.02 jumlah mortarnya relatif lebih banyak jika dibandingkan dengan campuran pada V.01. Kondisi kelebihan mortar dan karena bentuk dari terak nikel yang tidak 
beraturan dan berlubang mengakibatkan mortar masuk mengisi bagian-bagian yang kosong pada agregat kasar terak nikel, sehingga memberikan ikatan yang lebih baik dan saling mengunci yang mengakibatkan nilai slump menjadi lebih rendah.

Pada kondisi V.03, agregat halus yang berasal dari terak nikel berat volumenya lebih besar daripada agregat alami (V.01), maka volume mortar yang ada akan semakin sedikit. Dengan demikian ikatannya berkurang dibandingkan dengan yang menggunakan agregat halus alami. Hal ini mengakibatkan adukan beton menjadi turun dan nilai slump meningkat. Sedangkan pada kondisi penggunaan terak nikel sebagai agregat kasar dan halus secara bersamaan (V.04) mengakibatkan terjadi kombinasi pengaruh keduanya, adukan beton yang mengalir karena penggunaan agregat halus terak nikel dapat diimbangi oleh efek mengunci dari agregat kasarnya sehingga kenaikan nilai slump tidak sebesar pada saat penggunaan terak nikel sebagai agregat halus (V.03), namun lebih besar jika dibandingan dengan penggunaan agregat alami (V.01).

\section{Pengaruh Penggunaan Terak Nikel Sebagai Agregat dalam Campuran Beton Terhadap Sifat Mekanis Beton}

Sifat mekanis beton yaitu kuat tekan beton, modulus elastisitas dan kuat tarik belah beton sangat dipengaruhi oleh material penyusun beton (Mulyono, 2003). Penggunaan terak nikel sebagai agregat kasar dalam campuran beton (V.02) menyebabkan terjadinya peningkatan sifat mekanis beton jika dibandingkan dengan beton yang menggunakan agregat alami (V.01). Seperti yang telah dijelaskan sebelumnya, dengan jumlah volume mortar yang lebih banyak dibandingan dengan kondisi V.01, mortar yang ada dapat mengisi dan menyelimuti agregat kasar dengan lebih baik sehingga ikatan pada daerah transisi menjadi lebih kuat yang selanjutnya akan meningkatkan kuat tekan, modulus elastisitas dan kuat tarik belah beton. Seperti pengaruhnya terhadap nilai slump, sifat mekanis beton juga dipengaruhi oleh bentuk agregat kasarnya. Terjadinya ikatan yang baik antara mortar dengan agregat kasar yang berasal dari terak nikel dimana permukaannya tidak beraturan dan umumnya berlubang, mengakibatkan meningkatnya kuat tekan, modulus elastisitas dan kuat tarik belah beton karena mortar mengisi lubang pada agregat kasar dan bersifat memperkuat serta memperkokoh agregat kasar dalam campuran beton.
Pada kondisi V.03, akibat berat volume terak nikel sebagai agregat halus yang lebih besar daripada agregat alami (V.01), maka volume mortar dalam campuran beton menjadi lebih sedikit dibandingkan dengan penggunaan agregat alami. Mortar yang ada volumenya tidak mencukupi untuk menyelimuti agregat kasar alami sehingga ikatan yang terjadi pada daerah transisi beton menjadi lemah. Hal ini mengakibatkan terjadinya penurunan kuat tekan beton, modulus elastisitas dan kuat tarik belah beton.

Pada penggunaan secara bersamaan terak nikel sebagai agregat kasar dan halus (V.04) mengakibatkan jumlah pasta semen menjadi lebih banyak akibat pengaruh perubahan perbandingan volume agregat dalam campuran. Dengan kondisi bentuk agregat kasar dari terak nikel yang tidak beraturan dan berlubang serta jumlah pasta semen dalam campuran yang lebih banyak mengakibatkan kuat tekan, modulus elastisitas dan kuat tarik belah beton menjadi lebih baik dibandingkan dengan V.01 dan V.03. Pada kondisi V.04 juga merupakan kombinasi pengaruh dari kondisi V.02 dan V.03, dimana lemahnya ikatan mortar pada V.03 dapat diimbangi oleh efek mengunci pada kondisi V.02, sehingga kuat tekan, modulus elastisitas dan kuat tarik belahnya menjadi lebih baik dibandingan V.01 dan V.03, namun lebih rendah jika dibandingkan dengan V.02.

Kecenderungan hasil penelitian ini sesuai dengan hasil penelitian tentang penggunaan terak nikel sebagai agregat yang telah dilakukan oleh Khosama (1997) dan Sugiri (2005).

\section{SIMPULAN DAN SARAN}

\section{Simpulan}

Berdasarkan hasil pengujian terhadap penggunaan terak nikel sebagai agregat dalam campuran beton dapat disimpulkan hal-hal sebagai berikut :

1. Penggunaan terak nikel sebagai agregat dalam campuran beton mempengaruhi nilai slump beton jika dibandingkan dengan beton yang menggunakan agregat alami.

- Sebagai agregat kasar, terak nikel menyebabkan nilai slump turun sebesar $39,47 \%$.

- Sebagai agregat halus, terak nikel menyebabkan peningkatan nilai slump sebesar 55,26\%.

- Sebagai agregat kasar dan halus secara bersama-sama, terak nikel menyebabkan peningkatan nilai slump sebesar $34,21 \%$. 
2. Penggunaan terak nikel dalam campuran beton berpengaruh terhadap sifat mekanik beton (kuat tekan, modulus elastisitas dan kuat tarik belah), jika dibandingkan dengan beton yang menggunakan agregat alami.

- Sebagai agregat kasar, terak nikel meningkatkan nilai kuat tekan, modulus elastisitas dan kuat tarik belah berturutturut sebesar 42,27\%, 19,37\% dan $23,46 \%$.

- Sebagai agregat halus, terak nikel mengakibatkan nilai kuat tekan, modulus elastisitas dan kuat tarik belah turun berturut-turut sebesar $16,75 \%$, $6,70 \%$ dan $24,58 \%$.

- Sebagai agregat kasar dan halus secara bersama-sama, terak nikel meningkatkan nilai kuat tekan, modulus elastisitas dan kuat tarik belah berturutturut sebesar $10,31 \%, 9,26 \%$ dan $6,70 \%$.

Saran

Saran-saran yang dapat diberikan sehubungan dengan penelitian ini adalah sebagai berikut :

1. Berdasarkan hasil penelitian, limbah terak nikel kategori low slag dapat digunakan sebagai agregat dalam campuran beton jika ditinjau dari kuat tekan, modulus elastisitas dan kuat tarik belahnya. Terak nikel ini sebaiknya digunakan sebagai agregat kasar karena telah memiliki ukuran butiran sesuai dengan ukuran butiran agregat kasar yang biasa digunakan untuk campuran beton.

2. Perlu diteliti tentang permeabilitas beton yang menggunakan terak nikel sebagai agregat.

3. Perlu diteliti lebih lanjut tentang penggunaan agregat terak nikel dengan menggunakan rancangan campuran dalam perbandingan volume mengingat adanya perbedaan berat volume antara agregat alami dan agregat dari terak nikel

\section{DAFTAR PUSTAKA}

Atkins H.N. 2003. Highway Materials, Soils, and Concretes, Four Edition. Upper Saddle River , New Jersey 07458. Pearson Education Inc.

Badan Standarisasi Nasional. 1990. SNI 031971-1990, Metode Pengujian Kadar Air Agregat. Bandung.

Badan Standarisasi Nasional. 1990. SNI 031974-1990, Metode Pengujian Kuat Tekan Beton. Bandung.

Badan Standarisasi Nasional. 1996. SNI 034142-1996, Metode Pengujian Jumlah Bahan Dalam Agregate Yang Lolos
Saringan Nomor $200 \quad(0,0075 \quad \mathrm{~mm})$.

Bandung.

Badan Standarisasi Nasional. 1998. SNI 034804-1998, Metode Pengujian Bobot Isi Dan Rongga Udara Dalam Agregat. Bandung.

Badan Standarisasi Nasional. 2002. SNI 032491-2002, Metode Pengujian Kuat Tarik Belah Beton. Bandung.

Badan Standarisasi Nasional. 2008. SNI 1969:2008, Cara Uji Berat Jenis dan Penyerapan Air Agregat Kasar. Bandung.

Badan Standarisasi Nasional. 2008. SNI 1970:2008, Cara Uji Berat Jenis dan Penyerapan Air Agregat Halus. Bandung.

Badan Standarisasi Nasional. 2008. SNI 1972:2008, Cara Uji Slump Beton. Bandung.

Badan Standarisasi Nasional. 2008. SNI 2417:2008, Cara Uji Keausan Agregat Dengan Mesin Abrasi Los Angeles. Bandung.

Hindarko S. 1999. Bahan dan Praktek Beton. Jakarta. Erlangga.

Khosama L. K. 1997. Penggunaan Terak Nikel Sebagai Agregat Pada Beton Mutu Tinggi (tesis). Bandung. Institut Teknologi Bandung.

Martinus R. dkk. 2002. Laporan Praktikum Uji Bahan. Kendari. Universitas Haluoleo.

Mulyono, T. 2003. Teknologi beton. Jogyakarta. Andi.

Sukirman S. 1995. Perkerasan Lentur Jalan Raya. Bandung. Nova.

Sugiri, S. 2005. Penggunaan Terak Nikel Sebagai Agregat Dan Campuran Semen Pada Beton Mutu Tinggi. Jurnal Infrastruktur dan Lingkungan Binaan. Vol.: I. (1), 1-8.

Tjokrodimuljo K. 1996. Teknologi Beton. Yogyakarta. Nafiri.

Yayasan Dana Normalisasi Indonesia. 1971. Peraturan Beton Bertulang Indonesia 1971 N.I. 2. Bandung. 